\title{
Observations of a New Baroclinic Current along the Western Continental Slope of Bass Strait*
}

\author{
P. G. Baines, ${ }^{\mathrm{A}}$ R. J. Edwards ${ }^{\mathrm{B}}$ and C. B. Fandry ${ }^{\mathrm{C}}$ \\ A Division of Atmospheric Physics, CSIRO, P.O. Box 77, Mordialloc, Vic. 3195. \\ B Division of Oceanography, CSIRO, P.O. Box 21, Cronulla, N.S.W. 2230. \\ c Australian Numerical Meteorology Research Centre, P.O. Box 5089AA, Melbourne, Vic. 3001.
}

\section{Abstract}

Recent observations reveal the existence of a southward flowing baroclinic current over the continental slope of western Bass Strait. This current appears to be a permanent feature (though of variable strength), and some drifting-buoy observations suggest that it may extend to the southern tip of Tasmania.

There have been very few subsurface observations in the Bass Strait area west of King Island (Newell 1961). During 11-13 November 1980, with the cooperation of the Australian Antarctic Division, four expendable bathythermograph (XBT) sections with close sampling $(\sim 10-\mathrm{km}$ spacing) were taken from the Nella Dan over the western continental slope (Fig. 1), as part of a program coordinated by the Victorian Institute of Marine Sciences. All four sections showed a pronounced depression of the isotherms shelfward, and a representative section $\mathrm{AA}^{\prime}$ is shown in Fig. 2. Because of the spacing of the sections in time, this isotherm depression is clearly not tidal, although some internal tidal motion may have been present. If we assume that temperature is monotonically related to density, this implies a southward geostrophically balanced current along the slope.

Some stations at which samples were taken with a Nansen bottle from R.V. Sprightly on 10 December 1980 showed a similar isotherm depression and provided a relation between density and temperature in this region; the relationship is linear for temperatures below $13^{\circ} \mathrm{C}\left[\sigma_{\mathrm{t}}=26 \cdot 94-0 \cdot 07(T-8)\right]$, with salinity compensating for $50 \%$ of the temperature variation. Applying this relation to the (more closely spaced) sections of November 1980, we obtain a transport of $1 \cdot 1 \pm 0 \cdot 2$ Sv. Other XBT sections taken from Sprightly on 23 July 1980 and by J. Boyd from Nella Dan on 9 January 1981 also show the same general depression of isotherms. In addition, data from all available XBT stations, which were randomly scattered in space and time, in the area to January 1980 were obtained from the Australian Oceanographic Data Centre; when these were arranged in $10-\mathrm{km}$ wide strips parallel to the $200-\mathrm{m}$ contour, the same isotherm depression was apparent. All these pieces of evidence suggest that the current is a permanent feature, although its strength is variable.

Further evidence for the existence of this current comes from the observed paths of satellite-tracked buoys drogued at $20 \mathrm{~m}$. Approximately 38 such buoys were released by the Australian Bureau of Meterorology in the waters around Australia as part of the

*This paper is dedicated to Mr B. V. Hamon in recognition of his important contribution to physical oceanography in Australia.

0067-1940/83/010155\$02.00 
First GARP (Global Atmospheric Research Programme) Global Experiment (Grieg 1980). Of these, only one drifted into the continental slope region west of Bass Strait and Tasmania, and this track is shown (track 1) in Fig. 1; the track faithfully follows the topographic contours, with speeds on some days exceeding $50 \mathrm{~cm} \mathrm{~s}^{-1}$, around to the south-east corner of Tasmania. On 12 December 1980, two further buoys were released by G. Cresswell, one on the Bass Strait shelf (track 3) and the other over the slope (track 2); these tracks are also shown in Fig. 1. Again, southward motion over the slope was observed, contrasting with westward motion over the shelf. Hence, all the known relevant observations testify to the existence of this current, which we have named the 'Zeehan Current' after the name of one of Tasman's vessels.

Fig. 1
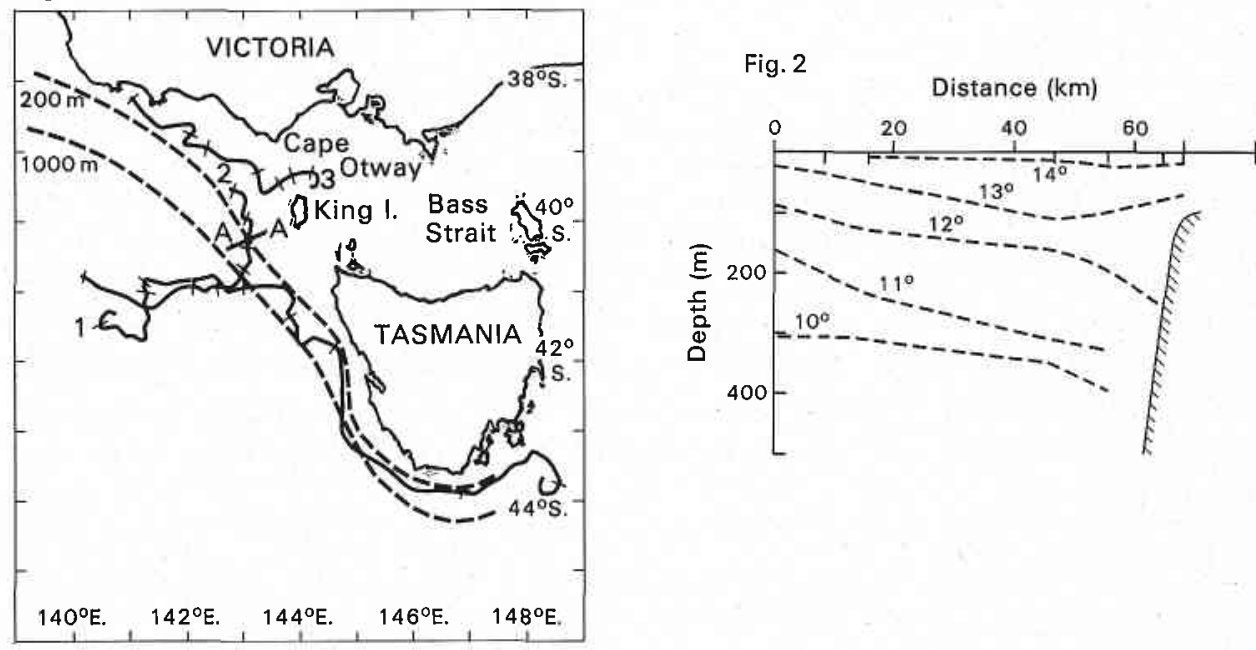

Fig. 1. Buoy tracks, bottom contours and location of XBT section AA' shown in Fig. 2. Other sections mentioned are situated within $100 \mathrm{~km}$ to the north-west and south-east of $\mathrm{AA}^{\prime}$. Tracks are numbered at their release points and commenced at the following dates: 1 , day 87,$1979 ; 2$, day 344,$1980 ; 3$, day 344,1980 . Tick marks on tracks denote 10 -day intervals.

Fig. 2. Temperature structure of section $\mathrm{AA}^{\prime}$ shown in Fig. 1, taken on 12 November 1980.

The width of the current $(\sim 40 \mathrm{~km})$ is of the order of the baroclinic Rossby deformation radius, so that the current may be regarded as a baroclinic Kelvin wave of zero frequency. It has a similar structure to that of the Leeuwin Current (Cresswell and Golding 1980), of which it could not be a continuation because of the difference in water types. No similar current has been found at the eastern edge of Bass Strait; however, the XBT sections taken in November 1980 also indicate that the underwater waterfall effect (Godfrey et al. 1980) observed at the eastern edge may occasionally occur at the western edge. An explanation for the presence of both the Leeuwin Current and the Zeehan Current has been given by Thompson and Veronis (1983) in terms of the westerly wind stress over the Indian Ocean and (in the case of the Zeehan Current) the Bight area.

This current may so far have gone unnoticed because of its narrowness ( $\sim 40 \mathrm{~km})$ and because, near Bass Strait, its surface manifestation may often be overwritten by direct wind effects. Along the west coast of Tasmania, shipping (which one might expect to report such a current) is practically negligible today, vessels which travel from Melbourne to Hobart preferring the more sheltered and shorter east coast route. In one 
sense, however, the current may have had some historical impact. In the days of sail, vessels from Europe to Melbourne frequently travelled the great circle route and would approach the Cape Otway-King Island gap from the south-west (Blainey 1966). Many such vessels-30 ships in a 26-year period (Villiers 1974) -were wrecked on the shores of King Island, often with great loss of life: Although there are doubtless many and varied reasons for this (bad weather, errors of navigation), it is likely that this current may have been a contributing factor. A slow-moving vessel making 4 knots would be displaced $10 \mathrm{~km}$ transversely southward in $40 \mathrm{~km}$ by a current of $50 \mathrm{~cm} \mathrm{~s}^{-1}$, and this could occur before land or the Cape Otway or King Island lights were sighted.

\section{Acknowledgments}

The authors are most grateful to the Antarctic Division for the use of the facilities of the Nella Dan and the cooperation of cruise leader Dr Knowles Kerry, to Dr John Boyd for the provision of the data taken on 9 January 1981, and to the Australian Oceanographic Data Centre for provision of the available bathythermograph data in the area.

\section{References}

Blainey, G. (1966). 'The Tyranny of Distance.' (Sun Books: South Melbourne.)

Cresswell, G. R., and Golding, T. J. (1980). Observations of a south-flowing current in the south eastern Indian Ocean, Deep Sea Res. 27, 449-66.

Godfrey, J. S., Jones, I. S. F., Maxwell, J. G., and Scott, B. D. (1980). On the winter cascade from Bass Strait into the Tasman Sea. Aust. J. Mar. Freshw. Res. 31, 275-86.

Greig, M. A. (1980). Satellite-tracked buoy data report V. Bureau of Meteorology buoys tracked in the Southern, Indian and Pacific Oceans. January to March 1979. CSIRO Aust., Div. Fish. Oceanogr. Rep. No. 120.

Newell, B. S. (1961). Hydrology of south-east Australian waters: Bass Strait and New South Wales tuna fishing area. CSIRO Aust., Div. Fish. Oceanogr. Tech. Pap. No. 10.

Thompson, Rory O. R. Y., and Veronis, George (1983). Poleward boundary current off Western Australia. Aust. J. Mar. Freshw. Res. 34, 173-85.

Villiers, Alan. (1974). 'Vanished Fleets—Sea Stories from Old Van Diemen's Land.' (Cat and Fiddle Press: Hobart.) 